\title{
KONSEP PENDIDIKAN DAN KEBEBASAN ANAK PUNK STREET
}

\author{
Siti Nurul Hidayah \\ Institut Ilmu Keislaman Zainul Hasan (INZAH) Genggong Probolinggo \\ nurulhidayah804@gmail.com \\ Bela Fariza \\ Institut Ilmu Keislaman Zainul Hasan (INZAH) Genggong Probolinggo
}

\begin{abstract}
Abstrak
Penelitian ini bertujuan untuk mengetahui bagaimana konsep diri anak punk street dalam mengintrepretasikan antara pendidikan dan kebebasan. Fokus dalam penelitian ini adalah mengetahui konsep diri anak punk street. Penelitian ini menggunakan metode penelitian kualitatif deskriptif, dengan menggunakan paradigma interpretatif. Pemilihan informan dalam penelitian ini menggunakan teknik purposive sampling. Adapun teknik pengumpulan data dengan menggunakan wawancara mendalam, observasi partisipatif, dan catatan lapangan. Hasil penelitian ini menunjukan bahwa konsep diri anak punk street dalam segi pendidikan adalah hanya bayang-bayang, yang mana adanya keterbatasan ekonomi membuat mereka menghilangkan keinginan untuk melanjutkan pendidikan dan lebih memilih kebebasan hidup dijalan dengan mengamen dan mendapatkan uang. Sedangkan dalam segi kebebasan adalah merupakan kehidupan mereka, kebebasan bagi anak punk street merupakan ideologi mereka sebagai jalan untuk mengenalkan jati diri kepada masyarakat, dengan menggunakan style punk, hidup di jalan, dengan mengamen merupakan kebebasan bagi anak punk street.
\end{abstract}

Kata kunci: Konsep Diri, Pendidikan, Kebebasan, Anak Punk Street

\begin{abstract}
This study aims to determine how the self-concept of punk street children in interpreting between education and freedom. The focus of this research is to know the self-concept of punk street children. This research uses descriptive qualitative research methods, using interpretive paradigms. The selection of informants in this study used a purposive sampling technique. The data collection techniques using in-depth interviews, participatory observation, and field notes. The results of this study indicate that the self-concept of punk street children in terms of education is only a shadow, where the existence of economic limitations makes them eliminate the desire to continue their education and prefer the freedom of life on the street by singing and earning money. While in terms of freedom is their life, freedom for punk street children is their ideology as a way to introduce identity to the community, using the punk style, life on the street, with busking is freedom for punk street children.
\end{abstract}

Keywords: Self Concept, Education, Freedom, Punk Street Children

\section{PENDAHULUAN}

Indonesia merupakan salah satu dari sekian banyak negara di dunia dengan jumlah populasi anak jalanan yang cukup besar. Data dari Kementerian Sosial RI menyebutkan bahwa pada tahun 2019 jumlah anak jalanan di Indonesia mencapai 135.139 anak dan tersebar di beberapa kota besar seperti Jakarta, Medan, Surabaya, Semarang, Bandung dan Yogyakarta, dll (Kemensos RI, 2019).

Banyaknya anak jalanan di Indonesia merupakan persoalan sosial yang masih banyak kita temukan di sekitar kita. Hidup menjadi anak jalanan memang bukan merupakan pilihan yang menyenangkan, karena mereka berada dalam kondisi yang tidak bermasa depan yang jelas, dan keberadaan mereka tidak jarang menjadi "masalah" bagi banyak pihak, keluarga, masyarakat bahkan negara.

Anak jalanan sering kita jumpai di pinggir-pinggir jalan raya, seperti pengamen, pengemis, pemulung, dan ada juga anak jalanan yang unik yang sering kita jumpai pada sekelompok pemuda berpakaian dan bergaya aneh yang sedang berkumpul di pinggiran jalan, di bawah 
pohon, di samping lampu merah bahkan di trotoar-trotoar. Anak jalanan yang sering kita jumpai disekitar kita ada yang paling khas dan unik, mereka adalah anak Punk street. Tampilan mereka yang beda dari anak jalanan pada umumnya mempunyai ciri khas tersendiri.

Anak punk street adalah salah satu dari sekian banyak anak jalanan, hanya saja penampilan mereka yang berbeda dari anak jalanan lainnya. Anak punk street merupakan fenomena yang banyak yang kita jumpai pada saat ini, mewabahnya anak punk street di jalanan merupakan salah satu dampak dari kurangnya kesejahteraan pada suatu negara. Banyaknya anak punk street di jalanan merupakan sebuah pilihan untuk menggapai hidup dengan kebebasan tanpa beban, dengan penampilan yang unik yang menjadi ciri khas tersendiri bagi mereka seperti berpakaian hitam, memakai jaket kulit, celana jeans ketat, bersepatu boots, menggunakan gelang berduri, memakai tindik atau pierching, berambut mohawk, dan bertato serta hidup di jalanan.

Gaya dan simbol di atas yang ditampilkan oleh anak punk street di jalanan sering dianggap mengganggu masyarakat, karena penampilan mereka yang sangat ekstrem bagi yang melihatnya. Gaya yang ditampilkan mereka di jalanan merupakan suatu keharusan, karena bagi mereka gaya yang ekstreem seperti itulah merupakan ciri khas mereka, seperti ideologi yang dimiliki anak punk street yaitu kebebasan. Hidup dengan penuh kebebasan tanpa aturan yang membelenggu mereka sehingga mereka dapat menemukan jati diri yang mereka harapkan.

Banyaknya anak punk street yang kita jumpai di jalanan merupakan akibat dari adanya persoalan dalam perekonomian bahkan sosial, adanya permasalahan tesebut menjadikan mereka anak jalanan yang bebas, tanpa aturan bahkan tanpa memperdulikan keluarga dan pendidikan. Bahkan banyak kita jumpai anak punk street yang putus sekolah demi untuk hidup di jalanan.

Pendidikan bagaikan tidak penting bagi hidup mereka, yang terpenting bagi mereka hidup dengan bebas di jalanan dengan cara mengamen dan mendapatkan uang untuk hanya sekedar menyambung hidup maupun untuk bersenang-senang.

Setiap anak punk street dari apa yang mereka tampilkan di jalanan memiliki konsep diri untuk mengekspresikan apa yang ada pada diri mereka, salah satunya dalam mengespresikan suatu kebebasan di dalam kehidupannya, mereka hidup dengan adanya kebebasan yang tidak terikat oleh apapun termasuk keluarga. Kebebasan merupakan ideologi bagi anak punk street, hidup mereka hanya untuk di jalanan mengamen, mendapatkan uang untuk bertahan hidup yang sesuai mereka inginkan tanpa adanya aturan yang mengikat mereka.

Kebebasan adalah salah satu yang tak bisa lepas dari anak punk street, karena mereka hidup dengan kebebasan tanpa adanya aturan apapun, tidak memperdulikan keluarga, bahkan pendidikan. Dari adanya realita yang terjadi pada anak punk street, bahwa anak punk street memiliki dua sisi kehidupan, di lingkungan keluarga dan di jalanan, yang mana kedua sisi ini berhubungan erat dengan pendidikan dan kebebasan hidup mereka. Maka adanya persoalan itu peneliti ingin mengetahui konsep diri anak punk street dalam mengintreprestasikan bagaimana mereka dalam memaknai pendidikan dan kebebasan di dalam kehidupan mereka.

Setiap individu pasti akan menghasilkan konsep diri yang berbedabeda baik dari segi individu itu sendiri maupun dari penilaian individu lain. Karena setiap apapun yang kita tampilkan akan menimbulkan kesan bagi yang melihatnya, seperti halnya anak punk street sebagai salah satu anak jalanan yang cukup unik diantara anak jalanan lainnya, juga memiliki konsep diri yang mereka tampilkan. Sedangkan dalam penelitian ini lebih memfokuskan pada konsep diri anak punk street itu sendiri dalam memaknai pendidikan dan kebebasannya.

Berdasarkan latar belakang dan uraian di atas maka dalam penelitian ini penulis merumuskan masalah sebagai berikut: "Bagaimana konsep diri anak punk street dalam mengintrepretasikan antara 
pendidikan dan kebebasan dalam kehidupan mereka".

\section{METODE}

Pendekatan yang digunakan dalam penelitian ini adalah Pendekatan kualitatif deskriptif, dengan menggunakan paradigma interpretatif. Paradigma interpretatif dimulai dari suatu fenomena yang ada di lapangan selanjutnya didalami untuk menghasilkan teori tujuannya ialah untuk memahami makna atas pengalaman seseorang atau sekelompok orang dalam suatu peristiwa pengalaman bukan kenyataan empirik yang bersifat obyektif, melainkan pelajaran yang bisa dipetik dari peristiwa yang dilalui seseorang.

Alasan peneliti dalam penelitian ini menggunakan paradigma intrepretatif adalah karena peneliti ingin mengetahui secara mendalam masalah anak punk street dalam menyikapi konsep diri mereka dari segi pendidikan dan kebebasan. Adapun subyek dalam penelitian ini adalah anak punk street. Sedangkan teknik dalam pengambilan informan menggunakan purposive sampling dimana teknik pengambilan sampel sumber data dengan pertimbangan tertentu, informan penelitian berjumlah tiga orang anak punk street. Lokasi Penelitian yang dilakukan oleh peneliti untuk mendapatkan data informan dilaksanakan di perempatan sumberrejo yang letaknya di persimpangan lampu merah.

Adapun yang menjadi pertimbangan peneliti sebagai tempat penelitian adalah karena di perempatan jalan di sumberrejo merupakan tempat para pengamen bergaya punk biasa mengamen untuk mencari nafkah. Pengumpulan data dalam penelitian ini melalui observasi, wawancara dan studi dokumentasi.

Observasi merupakan teknik pengumpulan data mempunyai ciri yang spesifik bila di bandingkan dengan teknik wawancara dan kuesioner, kalau wawancara dan kuesioner berkomunikasi dengan orang, maka observasi tidak terbatas pada orang, tetapi juga objek-objek alam yang lain.
Observasi dalam penelitian ini dilakukan dengan melakukan pengamatan secara langsung terhadap subyek dan obyek yang diteliti yaitu pada anak punk street, peneliti di sini terjun laangsung ke lapangan untuk mendapatkan data secara langsung ke Informan untuk mendapatkan data yang akurat dna relevan.

Wawancara dalam penelitian ini dilakukan dengan cara memberikan pertanyaan kepada anak punk street yang berada di perempatan jalan sumberrejo, Peneliti melakukan wawancara kepada para anak punk street punk sebagai informan inti. Dalam penelitian ini wawancara dilakukan secara terstruktur atau wawancara baku, yang mana peneliti telah menyiapkan pedoman wawancara dan informasi yang ingin diperoleh. Sedangkan Wawancara digunakan dalam penelitian ini untuk mengetahui fenomena kehidupan anak punk street dari segi kebebasan, agama dan pendidikan.

Studi Dokumentasi merupakan penelaah terhadap referensi-referensi yang berhubungan dengan focus permasalah penelitian. Dalam penelitian ini studi dokumentasi dilakukan dengan mencari data tambahan. Studi Dokumentasi dalam penelitian ini digunakan untuk mengetahui atau mengidentifikasi konsep diri anak punk street.

Analisis data dalam penelitian ini dilakukan oleh peneliti semenjak awal, pada setiap aspek kegiatan penelitian. Dan menurut menurut Miles dan Huberman (1986) menyatakan bahwa analisis data kualitatif tentang mempergunakan kata-kata yang selalu disusun dalam sebuah teks yang diperluas atau dideskripsikan.

Berdasarkan paradigma dan pendekatan dalam penelitian ini adalah menggunakan paradigma interpretatif maka analisis data dalam penelitian ini dilakukan secara kualitatif deskriptif berdasarkan hasil observasi terhadap pendeskripsian konsep diri anak punk street dari segi pendidikan dan kebebasan, maka adapun langkahlangkah analisis data yang peneliti gunakan adalah analisis data model Miles dan Huberman yang dilakukan dalam penelitin studi kasus ini adalah sebagai berikut : (1) reduksi data; (2) display atau penyajian 
data; (3) verivikasi atau mengambil kesimpulan.

Pertama Reduksi data, peneliti melakukan pengumpulan data dengan cara memilih milih data yang pokok dan yang penting melalui observasi langsung untuk melihat anak punk street, observasi dilakukan untuk memperoleh data tentang bagaimana konsep diri anak punk street dari segi pendidikan dan kebebasan. Kedua Penyajian Data berbentuk teks naratif yang mana pada tahap ini peneliti menceritakan hasil observasi di lapangan. Ketiga Verifikasi (mengambil kesimpulan) merupakan analisis lanjutan dari reduksi data, dan penyajian data sehingga data dapat di simpulkan, dan peneliti masih berpeluang untuk menerima masukan.

Adapun verifikasi dalam penelitian yang dilakukan dari konsep diri anak punk street data yang diperoleh akan diolah dan dianalisis secara kualitatif deskriptif dengan menjabarkan secara teks naratif.

\section{HASIL DAN PEMBAHASAN}

Hasil penelitian yang telah dilakukan oleh peneliti tentang konsep diri anak punk street jika dilihat dari segi pendidikan dan kebebasan adalah sebagai berikut: Langkah awal dalam menginterpretasikan konsep diri anak punk street, menurut George Herbert Mead, pada dasarnya terdiri dari jawaban individu itu sendiri atas pertanyaan tentang "Siapa Aku". Adanya pertanyaan tersebut muncullah konsep diri, yang merupakan suatu kesadaran individu mengenai keterlibatannya hubungan sosial yang sedang berlangsung di kehidupannya.

Konsep diri merupakan hasil dari suatu proses kehidupan yang tidak kelihatan, yang menimbulkan tindakan-tindakan antara individu dengan individu lain. Hasil Konsep diri anak punk street dalam memaknai pendidikan dan kebebasan sebagai berikut:

\section{Konsep Diri Anak Punk Street dalam Memaknai Pendidikan}

Pendidikan adalah sarana atau tempat untuk menyiapkan generasi penerus, sehingga mampu untuk memperkuat jati diri suatu bangsa. Dengan pendidikan yang baik dan layak bagi anak-anak, maka akan bisa mengantarkan pada Negara yang lebih maju. Dimana Negara maju adalah Negara yang memiliki kualitas pendidikan yang baik.

Permasalahan pendidikan bukan hanya merupakan masalah tentang tumbuh kembang anak, namun juga untuk kesejahteraan anak itu sendiri. Sebuah kondisi di Indonesia yang gencar merencanakan gerakan wajib belajar sembilan tahun, namun masih banyak dijumpai anak yang putus sekolah dengan alasan ketidak mampuan biaya sekolah (pendidikan).

Dalam hal ini pendidikan dalam konsep diri anak punk street adalah hanya sebuah bayang-bayang mereka tentang sekolah. Sekolah dalam anggapan mereka adalah suatu hal yang menyenangkan, dimana mereka bisa bertemu dengan temanteman mereka di sekolah serta bisa belajar dan bermain bersama, dengan sekolah meraka juga bisa mamperoleh pengetahuan yang sebelumnya belum di ketahuinya. Hal ini di tunjukkan bahwa kata mereka sekolah itu menyenangkan.

Sesungguhnya anak punk street sebelum menjadi anak jalanan mereka itu pernah memperoleh pendidikan di bangku sekolah, sehingga mereka mampu mengatakan bahwa sekolah itu suatu hal yang menyenangkan. Namun mereka harus putus sekolah karena ketidakmampuan ekonomi keluarga mereka sehingga mengakibatkan mereka lebih memilih hidup dengan kebebasan dijalan-jalan untuk mencukupi kebutuhan hidupnya.

Alasan ketidakmampuan dalam perekonomian itulah yang mengakibatkan mereka lebih menikmati hidup di jalanan dengan kebebasan dari pada memikirkan pendidikan yang mereka anggap hanya sebuah bayangan yang akan sulit digapai.

Pendidikan menurut anak punk street merupakan suatu mainan yang mahal, dikatakan mainan mahal karena dengan ketidakmampuan ekonomi keluarga mereka, maka mereka tidak bisa sekolah seperti yang diinginkannya, yang bagi mereka sekolah itu adalah suatu hal yang sangat menyenangkan, seperti halnya sebuah mainan adalah merupakan benda yang dapat dijadikan bermain anak-anak 
untuk membuat mereka senang, dan ketika mainan itu mahal maka tidak semua anakanak bisa mendapatkannya dengan mudah.

Hal tersebut sama halnya dengan pendidikan dalam pandangan anak punk street jika tidak memiliki uang maka mereka tidak akan bisa melanjutkan sekolah untuk memperoleh pendidikan. Sehingga harapan dan keinginan mereka untuk mendapatkan pendidikan yang baik harus terkubur, dengan alasan ketidakmampuan ekonomi keluarga mereka, dan menjadikan mereka juga harus berpangku tangan kepada orang-orang untuk memberikan uang kepada mereka dengan cara mengamen di jalanan dengan penuh kebebasan.

Jadi diperoleh kesimpulan bahwa konsep diri anak punk street dalam memandang antara pendidikan dan kebebasan adalah satu kesatuan yang tidak dapat dipisahkan, dimana mereka tahu bahwa mereka adalah orang yang tidak mempunyai cukup uang, sehingga pendidikan bagi mereka hanya merupakan sebuah bayang-bayang yang sulit untuk dicapai dan digapai. Karena sekolah itu membutuhkan uang yang cukup banyak dan keluarga mereka tidak memiliki cukup uang untuk memperoleh pendidikan di bangku sekolah.

Konsep diri anak punk street dalam memaknai pendidikan hanya sebagai suatu hal yang mustahil, suatu banyangan yang sulit untuk mereka raih, walaupun ada keinginan yang besar untuk bisa menikmati pendidikan tetapi bagi mereka hanya sebuah harapan yang akan sulit untuk terjadi.

Sehingga mereka hanya menganggap pendidikan hanya sebuah bayangan yang akan bisa mereka gapai saat di dunia mimpi, tetapi pada dunia nyata pendidikan hanya sebuah banyangan semu, maka dari itu mereka lebih menikmati hidup dengan cara lain, yaitu dengan hidup dengan penuh kebebasan di jalanan untuk mendapatakan uang untuk mereka bertahan hidup.

\section{Konsep Diri Anak Punk Street dalam Memaknai Kebebasan}

Kebebasan adalah dapat melakukan segala hal sesuai keinginan mereka tanpa ada batasan yang mengikat. Anak punk street identik dengan kata kebebasan dalam hidup dan berpikir. Dengan adanya kebebasan anak punk street dapat mengekspresikan hidupnya sesuai yang mereka keinginan, tanpa ada yang membelenggu dan mengatur mereka.

Arti dari kata punk itu sendiri adalah punkers yaitu sebagai suatu kebebasan dan anti kemapanan yang mana mereka menjadi seorang punk ingin hidup dengan kebebasan karena mereka mengalami kebosanan dalam hidup mereka sehingga dapat menemukan jatidirinya.

Dengan berpenampilan punk dengan mentatto tubuhnya, pierching di telinga dan mulut membuat, memakai celana jeans robek, sepatu bots, mereka merasa menemukan kebebasan dalam kehidupannya yang membosankan.

Dengan meniru penampilan seorang punk dan bertindak sesusai dengan apa yang punk lakukan membuat mereka merasa menghilangkan kebosanan dalam hidupnya dengan menjalani kehidupan yang bebas di jalanan, dari hasil penjelasan kedua pendapat di atas, ada beberapa alasan mereka menjadi seorang anak punk (1) karena mereka ingin bebas atau kebebasan, (2) mereka bosan dengan kehidupan yang monoton, (3) mereka ingin bebas berekspresi, (4) menurut mereka dengan berpenampilan ala punk membuat mereka merasa bebas dari kebosanan hidup.

Penjelasan di atas dapat penulis tafsirkan bahwa anak punk street hidup dengan kebebasan sebagai suatu gerakan untuk menghilangkan kebosanan mereka, karena kekurangan dalam ekonomi, dengan punk mereka merasa bebas dalam berekpresi di dalam musik, sesuai dengan teori pendekatan flow yang mana perasaan yang timbul pada diri seorang manusia saat ia bertindak secara total di dalam kegiatan yang ia ikuti. Nakamura dan Csikszentmihalyi (2002) menerangkan bahwa seseorang yang mengalami flow akan menganggap aktivitas yang ia lakukan penting dan berharga untuk ia lakukan, terlepas dari ada atau tidaknya gol yang dapat dicapai dalam melakukan kegiatan tersebut. Individu yang mengalami flow biasanya terlibat secara intens di dalam 
kegiatan yang ia lakukan, sehingga tak jarang mereka cenderung untuk tidak sadar dengan waktu atau tempat (Schunk, Pintrich $\&$ Meece , 2008).

Maka dari itu anak punk street dalam memaknai kebebasan dalam hidup mereka adalah suatu bentuk dalam mengekspresikan kebosanan dalam ketidakmampuan dalam perekonomian, sehingga mereka melampiaskan dengan cara hidup di jalanan dengan cara mengamen untuk mendapatkan uang untuk mereka bertahan hidup, atau untuk sekedar menghilangkan kebosanan dalam hidup.

Hidup dengan penuh kebebasan tidak bisa lepas dari anak punk street, karena kebebasan merupakan suatu ideologi bagi anak punk, seperti halnya pendidikan bagi mereka hanya sebuah mimpi untuk bisa digapai, tetapi berbeda dalam memperoleh kebebasan bisa mereka dapatkan dengan cara hidup di jalanan, tanpa aturan yang mengikat mereka. Hidup mereka bebas tanpa beban karena dengan kebebasan itulah mereka menikmati kehidupannya.

Dari penjelasan di atas sesuai dengan teori konsep diri dari mead, di dalam hidup setiap individu pasti akan menghasilkan konsep diri dalam memaknai setiap keadaan yang terjadi dalam kehidupannya, seperti halnya konsep diri anak punk Street dalam memaknai pendidikan dan kebebasan dalam hidup mereka.

Kedua konsep diri tersebut merupakan satu kesatuan yang tidak dapat dipisahkan bagi anak punk street. Walaupun mereka hidup dengan penuh kebebasan di jalananan tanpa beban tetapi jauh di lubuk hati mereka merindukan pendidikan yang sulit mereka raih, karena keterbatasan ekonomi.

Selain anak punk street dalam memaknai konsep antara pendidikan dan kebebasan, berbeda dengan masyarakat dalam memaknai konsep diri yang ada pada anak punk street. Masyarakat menilai bahwa konsep diri yang dibawa anak punk street dalam pikiran mereka adalah kata urakan, nakal, suka mabuk-mabukan, seenaknya sendiri, berpenampilan tidak sopan, hama yang perlu di hilangkan. segala bentuk pendeskripsian negatif melekat pada anak punk street di masyarakat.

Maka dari itu konsep diri setiap individu akan berbeda pandangaan sesuai dengan apa yang ada fenomenanya. Konsep diri tidak bisa terlepas dari individu, setiap individu menghasilkan konsep diri yang berbeda-beda dalam memaknainya.

\section{SIMPULAN}

Tidak semua anak punk street lebih mementingkan kekebasan dari pada pendidikan, bagi sebagian anak punk street ada yang ingin melanjutkan pendidikan tetapi kondisi perekonomian dan masalah keluarga mereka yang menjadi halangan untuk melanjutkan pendidikan. Anak punk street lebih memilih menjalani hidup dengan kebebasan, dengan cara mengamen di jalan-jalan raya agar bisa melupakan keinginan mereka untuk melanjutkan pendidikan. Karena dengan adanya hidup dengan kebebasan membuat mereka merasa bebas berekpresi terhadap dunia yang membosankan ini.

Bagi para anak punk street hendaknya lebih mementingkan pendidikan karena pendidikan sangat penting bagi kehidupan. Walaupun terdapat berbagai masalah yang mengakibatkannya tidak melanjutkan dan mementingkan pendidikan dan lebih memilih hidup dengan cara kebebasan. Pendidikan bisa menjadikan awal perubahan bagi kehidupan, karena dengan belajar anak bisa menaklukan dunia. Pendidikan tidak mengekang kebebasan tetapi menjadikan dunia lebih berwarna.

Masyarakat hendaknya jangan memandang seseorang hanya dilihat dari penampilannya saja walaupun anak Punk identik dengan gaya berpakaian yang urakan, seperti tattoan, pierching, rambut mohak, hura-hura dan perilaku negatif lainnya cobalah untuk melihat pula latar belakang kehidupan mereka dan alasan apa yang menjadikan mereka seperti itu, yang lebih mementingkan kebebasan dari pada pendidikan. 
DAFTAR PUSTAKA

Iskandar, D. (2009). Metodologi Penelitian Pendidikan Dan Sosial (Kuantitatif Dan Kualitatif). Jakarta: Gaungpersada Press.

Mulyana, Deddy. 2008. Ilmu Komunikasi Suatu Pengantar. Bandung:PT. Remaja Rosdakarya.

Mulyana, Deddy. 2008. Metodologi Penelitian Kualikatif: Paradigma Baru Ilmu Komunikasi dan Ilmu Sosial Lainnya. Bandung: PT. Remaja Rosdakarya.

Pardede, Y. O. K. (2008). Konsep Diri Anak Jalanan Usia Remaja. Jurnal Psikologi. Volume 1, No. 2, Juni 2008. Diunduh dari http://ejournal.gunadarma.ac.id/index.p $\mathrm{hp} / \mathrm{psiko} /$ article/view/292.

Neuman, W. L. (1997) Social Research Methods: Qualitative and Quantitative Approaches in Social Works. New York: Columbia University.

Sugiyono, P. (2011). Metode Penelitian Kuantitatif Kualitatif Dan $R \& D$. Bandung: Ikapi.

Ulfa Amalia. 2008. Konsep Diri Remaja Punk. Yogyakarta. Universitas Islam Indonesia.
Utami, Rizky Putri. 2012. Konsep Diri Perempuan Punk di Bandung. Bandung. Universitas Padjajaran.

Wahidmurni, M. (2008). Cara Mudah Menulis Proposal Dan Laporan Penelitian Lapangan . Malang: Universitas Negeri Malang.

http://www.riaupos.co/57153-berita-buruhanak-punk-bentrok,-tiga-terluka.html) Diakses pada tanggal 25 Januari 2020 pukul 20.00 WIB.

http://riaupos.co/51440-berita--lima-anakpunk-diamankan-satpol-pp.html) Diakses tanggal 25 Januari 2020 pukul 20.00 WIB.

http://Psychology.uii.ac.id) Diakses tanggal 25 Januari 2020 pukul 22:00 WIB. (http://Library.fikom.unpad.aca.id).Dia kses tanggal 25 Januari 2020 pukul 22:00 WIB.

http://elib.unikom.ac.id/download.php?id=2 08171. Diakses tanggal 25 Januari 2020, pukul 19.00 WIB.

http://ariezpunk.blogspot.com/2011/03/artipunk.html. Diakses tanggal 25 Januari 2020 pukul 19.51 WIB.

http://ruangpsikologi.com/pendidikan/teoriflow-belajar-tidak-lagimembosankan/\#ixzz3d2m5FMB9. Diakses pada tanggal 25 Januari 2020 pukul 20.43 WIB. 